\title{
$\frac{100}{\mathrm{LuT}} \mathrm{RPES}$
}

\section{OCHRONA AUTONOMII CZŁOWIEKA W RAMACH WYBRANYCH GWARANCJI DOTYCZĄCYCH WOLNOŚCI ${ }^{* *}$}

\section{WPROWADZENIE}

Problematyka unormowań dotyczących wolności jest niezwykle złożona. System prawny uznaje oraz chroni wspominana wartość na różnych poziomach $^{1}$. Ze względu na funkcjonalną więźz zachodzącą między przepisami regulującymi wolność, a także ich wpływ na kształt godności osobowej nieprzypadkowe jest ich łączne analizowanie.

* Agnieszka Wojcieszak, Uniwersytet im. Adama Mickiewicza w Poznaniu, a.wojcieszak@amu.edu.pl, https://orcid.org/0000-0003-1739-4037

** Niniejszy artykuł stanowi fragment, dotychczas nieopublikowanej, rozprawy doktorskiej autorki.

${ }^{1}$ Zob. m.in. Preambuła, art. 55 pkt c, art. 62 ust. 2 Karty Narodów Zjednoczonych, Statut Międzynarodowego Trybunału Sprawiedliwości i Porozumienie ustanawiające Komisję Przygotowawczą Narodów Zjednoczonych (Dz. U. 1974, Nr 23, poz. 90 ze zm.); art. 1, art. 3, art. 13, art. 18-20 oraz pośrednio art. 2, art. 5-13 Powszechnej deklaracji praw człowieka uchwalonej przez Zgromadzenie Ogólne ONZ w dniu 10 grudnia 1948 r., <https://www.ohchr.org/en> [dostęp: 14.08.2019]; Preambuła, art. 6-9, art. 11-13, art. 18-19, art. 21-22 Międzynarodowego paktu praw obywatelskich i politycznych z 19 grudnia 1966 r. otwartego do podpisu w Nowym Jorku (Dz. U. 1977, Nr 38, poz. 167); Preambuła, art. 3, art. 6, art. 10-12 Karty praw podstawowych Unii Europejskiej (Dz. Urz. UE 2016 C 202: 389); Preambuła, art. 5, art. 11, rozdz. II: Wolności, prawa i obowiązki człowieka i obywatela, a w szczególności: art. 30, art. 31, art. 41, art. 52-54 Konstytucji RP (Dz. U. 1997, Nr 78, poz. 483 ze zm.); art. 23, art. 445 § 2 k.c.; rozdz. XXIII: Przestępstwa przeciwko wolności, szczególnie art. 189 oraz art. 217-217a ustawy z 6 czerwca 1997 r. - Kodeks karny (t.jedn.: Dz. U. 2020, poz. 1444 ze zm.); art. $96^{1}$ ustawy z 25 lutego 1964 r. - Kodeks rodzinny i opiekuńczy (t.jedn.: Dz. U. 2020, poz. 1359 ze zm.). Zob. też Balicki, Barciak, Preisner (1998): 55-59; Dudek (1999): 64-75.

${ }_{2}^{2}$ Zob. Radwański, Olejniczak (2019): 164; wyroki ETPC: z 26 lipca 2005 r. w sprawie Siliandin przeciwko Francji, skarga nr 73316/01, Legalis nr 132796; z 27 lutego 2007 r. w sprawie Akpinar i Altun przeciwko Turcji, skarga nr 56760/00, Legalis nr 130735. 
Wprawdzie wolność stanowi atrybut ludzkiej egzystencji, to niemożliwe jest jej pozytywnoprawne, całościowe zdefiniowanie i uregulowanie ${ }^{3}$. Występuje ona w rozmaitych supozycjach przedmiotowych, dlatego bywa niejednolicie rozumiana. Zazwyczaj dotyczy sfery wartości (ujęcie aksjologiczne) ${ }^{4}$, jednak zdarza się, że jest traktowana jako wymóg życia zbiorowości (np. narodu) albo zaleta gatunkowości ludzkiej ${ }^{5}$. Wolność należy również do pojęć ontologicznych. Rozpatrywana pozaaksjologicznie „odnosi się do sytuacji przedmiotu w bycie"6. Z tego też względu jest ona logicznie pierwotniejsza w ujęciu możliwościowym. Jawi się jako nadzwyczajne dobro, które przeciwstawiane jest stanowi niewoli 7 . W ten sposób „bycie wolnym” oznacza tyle co „istnieć soba tylko opierając się na wewnętrznej konstrukcji przedmiotowej i sile własnej zawartości ontycznej”. Nie oznacza to jednak wolności absolutnej, ponieważ nawet jeśli człowiek jest wolny, a posiada zaburzenia psychiczne (aspekt wewnętrzny), to ich istnienie może uniemożliwić mu podjęcie świadomej decyzji ${ }^{9}$.

Trzeba również zwrócić uwagę na aspekt filozoficzny wolności. Przyjmując bardzo ogólne założenie, wyróżnić można wolność negatywna, czyli brak przymusu i integracji z zewnątrz, oraz wolność pozytywna, związaną z samodecydowaniem ${ }^{10}$. Natomiast w ujęciu normatywnym wolność stanowi sferę działań niezakazanych przez ustawodawcę. Dzięki czemu człowiek może postępować zgodnie ze swoją wola bez ingerencji ze strony państwa (tj. władzy) ${ }^{11}$. Tym samym „dozwolone jest wszystko to, co nie jest zakazane” ${ }^{12}$. Pamiętać wszelako należy, że nośnikiem tak rozumianej wolności jest zarówno człowiek, jak i społeczeństwo. Z tego też względu najbardziej oczywista i uzasadniona zdaje się rola ograniczeń wolności indywidualnej względem podmiotu zbiorowego (tzw. delimitacja antropologiczna). Ten rodzaj delimitacji dotyczy korzystania z wolności przez człowieka w taki sposób, by nie naruszać wolności społeczeństwa. Natomiast przedmiotem delimitacji jest wolność drugiego człowieka ${ }^{13}$.

W piśmiennictwie szeroko prezentowane jest stanowisko, wedle którego autonomia, obok integralności i nietykalności cielesnej, stanowi aksjologiczny, systemowy oraz treściowy „rdzeń” szeroko pojmowanej wolności ${ }^{14}$, dlatego też $\mathrm{w}$ niniejszym artykule odniesiono się tylko do wybranych gwarancji ochrony wolności. Ich syntetyczne zaprezentowanie ma na celu ustalenie wzajemnej

\footnotetext{
${ }^{3}$ Dudek (1999): 21 i 147.

${ }^{4} \mathrm{Z}$ perspektywy aksjologicznej wyróżnia się trzy funkcje wolności: 1) środek do osiagania innych wartości; 2) miara dla ogółu lub wybranego zestawu wartości; 3) gwarancja dla bezpieczeństwa egzystencjalnej tożsamości podmiotu - zob. Lipiec (1997): 127-128.

${ }^{5}$ Lipiec (1997):107.

${ }^{6}$ Lipiec (1997): 108.

7 Sobolewski (2017): 390; Grzybowski (1957): 84; Lipiec (1997): 109.

8 Lipiec (1997): 111.

${ }^{9} \mathrm{Na}$ temat wolności zewnętrznej zob. m.in. Ławniczak (2010): 369.

10 Michałowska (2014): 20; zob. również Kazimierczuk (2014): 106; Kurowski (2014): 73; Bosek (2012): 202; wyrok TK z 18 lutego 2004 r., P 21/02, OTK-A 2004, nr 2, poz. 9.

${ }_{11}$ Chodzi o tzw. status negativus - zob. Bosek (2012): 160; Granat (2014): 97.

12 Augustyniak (2016): 15.

13 Lipiec (1997): 132, 134.

14 Zob. m.in. Dudek (1999): 10, 21, 147, 149; Lipiec (1997): 111-114.
} 
relacji między autonomia a wolnością w stosunkach prawnomedycznych. To natomiast pozwoli określić, czy gwarancje dotyczące wolności zapewniają właściwą ochronę autonomii.

\section{KONSTYTUCYJNE GWARANCJE OCHRONY WOLNOŚCI}

W pierwszej kolejności należy zwrócić uwagę na konstytucyjne gwarancje ochrony wolności zawarte $\mathrm{w}$ Preambule Konstytucji $\mathrm{RP}^{15}$. Wskazuje ona na historyczną oraz społeczną rolę wolności ${ }^{16}$, a ponadto wymienia ją jako oparcie dla praw podstawowych ${ }^{17}$. Ma ona charakter wartości uniwersalnej, która posiada niezwykle szeroki kontekst aksjologiczny. Z jednej strony stanowi obok sprawiedliwości oparcie dla państwa i systemu prawnego, z drugiej zaś - wraz z godnością człowieka należy do fundamentalnych kategorii prawnych.

Zauważyć trzeba również, że brzmienie Preambuły sugeruje istnienie „prawa do wolności”. Wydaje się, że jest to pewien skrót myślowy, ponieważ „wolność nie wynika z prawa, przeciwnie, to prawo może odnosić się do wolności, może ją normować, ale nie konstytuować czy przyznawać"18. Chodzi tu więc raczej o prawa i wolności człowieka i obywatela, których źródłem jest przyrodzona i niezbywalna godność człowieka.

Wyrazić należy pogląd, że wolność jest ontologicznie, aksjologicznie i prawnie „zakotwiczona” w godności ${ }^{19}$. Faktem jest, że art. 30 Konstytucji RP stanowi płaszczyznę kreowania systemu wartości powiązanego z ideą praw naturalnych ${ }^{20}$, a także „wyraża wolność kluczową z punktu widzenia aksjologii konstytucyjnej i nie może być pominięty wtedy, gdy chodzi o ocenę regulacji prawnych nakierowanych na ochronę najbardziej żywotnych interesów każdej osoby" ${ }^{21}$. Dlatego wolność w swym całokształcie stanowi wyraz poszanowania i urzeczywistniania godności ${ }^{22}$, natomiast godność kształtuje system ochrony wolności i praw człowieka i obywatela. Normatywne ich zawiązanie zakłada istnienie pewnego porządku wartości oraz tworzy „podmiotową jakość każdej jednostki ludzkiej”"23. W orzecznictwie wskazuje się, że „Konstytucja w całokształcie swych postanowień daje wyraz pewnemu obiektywnemu systemowi wartości [...] centralną rolę odgrywają postanowienia o prawach i wolnościach

15 Wstęp do Konstytucji RP ma szczególne znaczenie dla procesu wykładni, ponieważ zawiera pewne „dyrektywy interpretacyjne” - wyrok TK z 6 lipca 1999 r., P 2/99, OTK 1999, nr 5, poz. 103.

16 Zob. np. postanowienie TK z 6 marca 2001 r., S 1/01, OTK 2001, nr 2, poz. 35; wyrok TK z 28 maja 2003 r., K 44/02, OTK-A 2003, nr 5, poz. 44.

17 Bosek (2016): 757.

18 Dudek (1999): 81.

19 Bosek (2012): 201; zob. też Sarnecki (1997): 13; Granat (2014): 97.

${ }_{20}$ Kazimierczuk (2014): 111; Mazurek (1980): 19-47; Mrozek (2014): 41-47; podobnie wyroki TK: z 23 marca 1999 r., K 2/98, OTK 1999, nr 3, poz. 38; z 15 października 2002 r., SK 6/02, OTK-A 2002, nr 5, poz. 65.

21 Wyrok TK z 1 września 2006 r., SK 14/05, OTK-A 2006, nr 8, poz. 97.

22 Garlicki (2016): 37-41 i tam cytowana literatura.

${ }^{23}$ Bosek (2012): 109 i tam wskazana literatura. 
jednostki” ${ }^{24}$. Uznaje się, więc że,,wszelkie prawa i wolności wywodzą się z godności”, chociaż związek ten „nie jest taki sam w wypadku każdej z tych konstytucyjnych wolności i praw"25.

Nie mniejsze znaczenie posiada przepis art. 31 Konstytucji RP, który wysławia jedna z głównych gwarancji prawnej ochrony wolności człowieka ${ }^{26}$. Jej zakres wyznaczaja zarówno normy prawne, jak i społeczne, do których odsyłaja explicite lub implicite ustawowe lub konstytucyjne klauzule generalne ${ }^{27}$. W ten sposób traktowana jest albo jako norma ogólna, która nie znajduje zastosowania, gdy pozostające w zbiegu przepisy szczególne określają wolności konstytucyjnej $^{28}$, albo przeciwnie, czyli jako norma, która zawsze znajduje zastosowanie, również wtedy, gdy przepisy szczególne chronią wolność człowieka ${ }^{29}$. Biorąc pod uwage powszechnie aprobowaną dyrektywę lex specialis derogat legi genera$l i$, trafne wydaje się pierwsze z prezentowanych stanowisk. Niezależnie jednak od tego zasada prawnej ochrony wolności człowieka wyrażona w art. 31 ust. 1 Konstytucji RP ma niezwykle szeroki zakres i inny stopień abstrakcji niż poszczególne wolności konstytucyjne. W literaturze wskazuje się, że „w każdym aspekcie uregulowania musi być postrzegana przez pryzmat godności”30.

Szczególną uwagę należy poświęcić również wolności osobistej (art. 41 Konstytucji RP) ${ }^{31}$. Nie ma ona charakteru absolutnego, aczkolwiek stanowi źródło rozwoju osobowości człowieka ${ }^{32}$. Implikuje możliwość korzystania z innych praw, wolności oraz wartości wyrażonych w przepisach konstytucyjnych oraz aktach prawnych niższej rangi ${ }^{33}$. Abstrakcyjność i niejednoznaczność „wolności osobistej” powoduja, że niezwykle trudne jest właściwe jej definiowanie. Prima facie „wolność osobista” powinna być rozumiana dosłownie, czyli jako wolność osoby ludzkiej, obejmująca z jednej strony wewnętrzną personalną tożsamość i identyfikację podmiotową w otaczającym środowisku społecznym, z drugiej zaś - swobodę ocen i wyboru postępowania ${ }^{34}$. Szczególnym jej wyrazem jest możliwość podejmowania przez człowieka decyzji zgodnie z własną wola ${ }^{35}$. Wolność osobista pozwala zatem każdemu na dysponowanie swoja

\footnotetext{
${ }^{24}$ Wyrok TK z 23 marca 1999 r., K 2/98, OTK 1999, nr 3, poz. 38.

${ }^{25}$ Wyrok TK z 12 grudnia 2005 r., K 32/04, OTK-A 2005, nr 11, poz. 132.

${ }^{26}$ W literaturze postrzega się art. 31 ust. 1-2 Konstytucji RP jako „metanormę” - zob. zwł. Bosek (2016): 761.

${ }^{27}$ Bosek (2016): 758.

${ }^{28}$ Bosek (2016): 758; wyroki TK: z 6 października 2009 r., SK 46/07, OTK-A 2009, nr 9, poz. 132; z 10 lipca 2007 r., SK 50/06, OTK-A 2007, nr 7, poz. 75; z 1 marca 2011 r., P 21/09, OTK-A 2011, nr 2, poz. 7; z 20 grudnia 1999 r., K 4/99, OTK 1999, nr 7, poz. 165; z 7 maja 2002 r., SK 20/00, OTK-A 2002, nr 3, poz. 29; por. wyrok TK z 10 kwietnia 2002 r., K 26/00, OTK-A 2002, nr 2, poz. 18.

${ }^{29}$ Bosek (2016): 758; wyrok TK z 7 marca 2007 r., K 28/05, OTK-A 2007, nr 3, poz. 24.

${ }^{30}$ Łabno (2002): 695.

31 Dudek (1999): 140-147; Bosek (2012): 202.

${ }^{32}$ Podobnie wyrok TK z 20 listopada 2012 r., SK 3/12, OTK-A 2012, nr 10, poz. 123.

${ }^{33}$ Wiliński, Karlik (2016): 992; Wiliński (2011): 193.

${ }^{34}$ Dudek (1999): 144.

${ }^{35}$ Uchwała SN (7) z 13 marca 1990 r., V KZP 33/89, OSCN 1990, nr 7-2, poz. 23; podobnie wyroki TK: z 10 lipca 2007 r., SK 50/06, OTK-A 2007, nr 7, poz. 75; z 11 października 2011 r., K 16/10, OTK-A 2011, nr 8, poz. 80.
} 
osobą ${ }^{36}$. Pomimo nietrafnego zawężenia jej rozumienia do kontekstu represyjnego $^{37}$, stanowi wraz z nietykalnością osobista, autonomią i integralnościa fundament wolności człowieka w znaczeniu podstawowym ${ }^{38}$. Ten szczególny związek eksponuje stosunek art. 41 ust. 1 zd. 2 do art. 31 ust. 3 in fine Konstytucji RP ${ }^{39}$. Wprawdzie ustawodawca zakazuje wprowadzania takich ograniczeń, które mogłyby doprowadzić do naruszenia istoty wolności lub praw (art. 31 ust. 3 Konstytucji in fine RP), to obok ograniczenia wskazuje również możliwość pozbawienia wolności (art. 41 ust. 1 zd. 2 Konstytucji RP). Pojawia się na tym tle pytanie, jaki jest związek między wspominanymi przepisami oraz czy pozbawienie wolności nie stanowi nadmiernej ingerencji w wolność jednostki, prowadząc tym samym do naruszenia istoty tego prawa.

Bez wątpienia wskazane gwarancje mają szczególny charakter z perspektywy ochrony wolności konstytucyjnych. Wydaje się, że art. 41 ust. 1 zd. 2 stanowi lex specialis względem art. 31 ust. 3 in fine Konstytucji RP. Z jednej strony przepis ten wprowadza wyjątek w zakresie postępowania z wolnościa człowieka, z drugiej zaś - uzupełnia zasadę proporcjonalności. Nie wdając się w szczegółowe rozważania na ten temat, zauważyć należy, że nawet osoba pozbawiona wolności może realizować podstawowe prawa i wolności wynikajace z przysługującej każdemu człowiekowi godności. Potwierdza to niejako tezę, że wolność osobista stanowi jeden $\mathrm{z}$ wielu aspektów uniwersalnej wolności człowieka ${ }^{40}$. Oznacza to tym samym, że „pozbawienie wolności” w świetle art. 41 ust. 1 zd. 2 Konstytucji RP nie ma charakteru bezwzględnego, a człowiek może korzystać z innych przejawów szeroko rozumianej wolności (np. w zakresie ochrony własnych interesów).

Nadmienić należy, że również prawo do decydowania o swoim życiu osobistym ma kluczowe znaczenie w kontekście autonomii człowieka i gwarancji jej ochrony ${ }^{41}$. Przepis art. 47 Konstytucji RP nakazuje przyjąć istnienie obowiązku poszanowania oraz ochrony przez władzę publiczna sfery życia prywatne-

36 Przybyszewska-Szter (2016): 116.

37 Zob. zwł. art. 41 ust. 2-4 Konstytucji RP.

38 Por. wyrok TK z 11 czerwca 2002 r., SK 5/02, OTK-A 2002, nr 4, poz. 41.

39 Co do pozbawienia i ograniczenia wolności w ujęciu konstytucyjnym zob. szerzej zwł. Wiliński, Karlik (2016): 998-999; wyroki TK: z 5 stycznia 1999 r., K 27/98, OTK 1999, nr 1, poz. 1; z 13 maja 2009 r., Kp 2/09, OTK-A 2009, nr 5, poz. 66; z 17 maja 2012 r., K 10/11, OTK-A 2012, nr 5, poz. 51. Za pozbawienie wolności uznaje się również przymusowe umieszczenie osoby w szpitalu psychiatrycznym bez jej zgody (zob. wyrok ETPC z 21 grudnia 2010 r. w sprawie Witek przeciwko Polsce, skarga nr 13453/07, Legalis nr 300775; wyrok ETPC z 16 października 2012 r. w sprawie Kędzior przeciwko Polsce, skarga nr 45026/07, Legalis nr 1070036), a także przymusowe zatrzymanie w izbie wytrzeźwień (zob. wyrok ETPC z 4 kwietnia 2000 r. w sprawie Witold Litwa przeciwko Polsce, skarga nr 26629/95, Legalis nr 1029303).

40 Zob. np. wyrok TK z 7 marca 2000 r., K 26/98, OTK 2000, nr 2, poz. 57.

${ }^{41} \mathrm{~W}$ literaturze wskazuje się, że znamienne znaczenie dla obecnego kształtu art. 47 Konstytucji RP ma przepis art. 8 Konwencji o ochronie praw człowieka i podstawowych wolności sporządzonej w Rzymie dnia 4 listopada 1950 r., zmieniona następnie Protokołami nr 3, 5 i 8 oraz uzupełniona Protokołem nr 2 (Dz. U. 1993, Nr 61, poz. 284 ze zm.; dalej jako: EKPC). Znajduje to swoje odzwierciedlenie w orzecznictwie, gdzie bardzo często obok naruszenia art. 47 Konstytucji RP wskazuje się również na naruszenie art. 8 EKPC - zob. Wild (2016): 1170. Przy czym wspominane przepisy stanowią odrębne źródła gwarancji ochrony prywatności. Dlatego należy intepretować je niezależnie. Słusznie wskazuje się, że elementem je łączącym jest m.in. to, że 
go, rodzinnego, nienaruszalności czci i dobrego imienia oraz decyzji jednostki o jej życiu osobistym ${ }^{42}$. System prawny, gwarantując ochronę życia prywatnego, swym zakresem obejmuje również autonomię postrzeganą jako prawo do samodzielnego decydowania o swoim życiu osobistym ${ }^{43}$. Autonomia tworzy zasadniczy element prywatności, a niekiedy nawet argumentacji przy rozstrzyganiu, czy - i ewentualnie w jakich okolicznościach - prywatność naruszono.

\section{WOLNOŚĆ JAKO DOBRO OSOBISTE}

Z perspektywy zagadnień szczegółowych niezbędne zdaje się również nawiąanie do instytucji dóbr osobistych. Niewątpliwie wolność stanowi wartość właściwą każdemu człowiekowi i z tego też względu pozostaje pod ochrona prawa cywilnego (art. 23 k.c.) ${ }^{44}$. Kwestią dyskusyjną jest natomiast ustalenie jej znaczenia. Wydaje się, prima facie, że ze względu na swoją pojemność semantyczną wolność posiada wiele aspektów i przejawów, szczególnie w stosunkach prywatnoprawnych. Dlatego wśród przedstawicieli prawa cywilnego prezentowane sa dwa, odmienne, sposoby rozumienia tego wieloznacznego pojęcia ${ }^{45}$. Według pierwszego z nich wolność oznacza „fizyczną swobodę poruszania się" ${ }^{\prime 6}$. Jest to ujęcie raczej wąskie, które odwołuje się wyłącznie do stosowania przymusu fizycznego (np. bezpodstawne umieszczenie w szpitalu psychiatrycznym $)^{47}$. Z uwagi na pewne niedostatki wynikające $\mathrm{z}$ takiej konstrukcji dalej przyjęto, że przedmiotem ochrony jest „wolność od złośliwego niepokojenia" ${ }^{48}$. Uznanie tej koncepcji za właściwa prowadzi do ochrony całości życia uczuciowego człowieka, w szczególności spokoju psychicznego, a zatem ogólnego, nieograniczonego prawa osobistości. Z tego też względu uznać należy, że tzw. złośliwe niepokojenie stanowi naruszenie wolności, jeżeli oznacza zmuszanie do określonego zachowania.

Natomiast według drugiej koncepcji pojęcie wolności w świetle art. 23 k.c. powinno być rozumiane szeroko ${ }^{49}$, tj. z uwzględnieniem zarówno fizycznej swobody poruszania się, jak i swobody decydowania przez człowieka o swoich sprawach, przekonaniach, światopoglądzie, wolności od obawy, strachu,

swym zakresem obejmują szeroki krąg interesów jednostki. Na temat relacji art. 8 EKPC z art. 47 Konstytucji RP zob. zwł. Wild (2016): 1170-172.

${ }^{42}$ Wild (2016): 1162.

${ }^{43}$ Chodzi przede wszystkim o aspekt funkcjonalny autonomii człowieka - podobnie Boratyńska, Konieczniak (2019): 65-66.

${ }^{44}$ Podobnie wyrok SA w Białymstoku z 1 marca 1994 r., III APr 10/94, Lex nr 11756.

${ }^{45}$ Zob. m.in. Grzybowski (1957): 84; Radwański, Olejniczak (2019): 165.

${ }^{46}$ Grzybowski (1957): 84; podobnie wyrok SN z 9 maja 2003 r., V CK 344/02, Legalis nr 59865.

${ }^{47}$ Mularski (2016): 1849.

${ }^{48}$ Grzybowski (1957): 104-106. Na ten temat również m.in. Szpunar (1979): 125. Wydaje się, że ocena działania sprawcy przy kwalifikacji dóbr osobistych jest obojętna, a wyodrębnienie poszczególnych dóbr następuje wedle kryteriów określających przedmiot ochrony.

${ }^{49}$ Ochronę wolności w szerokim rozumieniu przewidują również przepisy art. 189 n. k.k. 
gróźb, przymusu psychicznego ${ }^{50}$. Chodzi więc o ochronę przed niedozwolonymi naciskami, które krępują dysponowanie wartościami osobistymi ${ }^{51}$. Tytułem przykładu wskazać można między innymi integralność seksualna, prawo do prywatności, nietykalność osobistą oraz swobodę sumienia ${ }^{52}$. Wymienione wartości zakwalifikowane zostały przez ustawodawcę lub orzecznictwo jako odrębne dobra osobiste, mimo że stanowia przejawy wolności sensu largo. Dzieje się tak, ponieważ wolność posiada wiele różnych ujęćs ${ }^{53}$, a to powoduje, że jej zakres obejmuje szereg różnych, często zgoła odmiennych wartości (np. nietykalność mieszkania, tajemnica korespondencji, swoboda sumienia, myśli i wyznania) ${ }^{54}$. Można w istocie podzielić pogląd, że wolność jest kategorią nadrzędna, ponieważ posiada niezwykle silne oparcie konstytucyjne ${ }^{55}$, przenika wszystkie sfery porządku prawnego (tj. prawo prywatne i prawo publiczne) oraz traktowana jest jako dyrektywa kształtowania instytucji prawnych ${ }^{56}$. Z punktu widzenia prawa cywilnego stanowi dobro osobiste, w którym oparcie oraz gwarancje ochrony znajdują inne, ściśle związane z człowiekiem wartości.

Wolność nie ma charakteru absolutnego. Podobnie jak inne dobra prawnie chronione, może podlegać ograniczeniom (art. 31 ust. 3 Konstytucji RP), a niekiedy stanowić przedmiot naruszenia. Zasadniczo naruszenie wolności może wynikać z zastosowania przymusu fizycznego lub psychicznego (np. w drodze nadużycia stosunku zależności), podstępu, groźby, a niekiedy także podjęcia decyzji za zainteresowanego (np. przeprowadzenie zabiegu operacyjnego bez zgody pacjenta).

W obecnym stanie prawnym wyraźnie przewidziano zadośćuczynienie pieniężne „w przypadku pozbawienia wolności” (art. $445 \S 2$ k.c.) ${ }^{57}$. Przez pozbawienie wolności należy rozumieć przypadki fizycznego uniemożliwienia człowiekowi nieskrępowanego postępowania czy odebranie mu swobody poruszania $\operatorname{się}^{58}$. Chodzi tu zwłaszcza o sytuacje bezpodstawnego umieszczenia w szpitalu psychiatrycznym ${ }^{59}$, niesłusznego zatrzymania, aresztowania ${ }^{60} \mathrm{lub}$

50 Zob. Dyka (2001): 609; Chaciński (2004): 121-122.

${ }^{51}$ Szpunar (1979): 126; por. wyrok SA w Katowicach z 28 listopada 1996 r., III APr 36/96, Legalis nr 34156.

52 Księżak (2014): 278.

${ }^{53}$ Zob. m.in. art. 31 ust. 1 i 2 Konstytucji RP (zasada ochrony wolności); art. 41 Konstytucji RP (wolność osobista); art. 52 (wolność poruszania oraz wyboru miejsca zamieszkania); art. 53 (wolność sumienia i religii); art. 54 (wolność wyrażania opinii oraz pozyskiwania i rozpowszechniania informacji).

54 Sokołowski (2012): 122-123.

55 Zob. wyrok SN z 21 listopada 2003 r., V CK 16/03, Legalis nr 106563.

56 Bosek (2016): 752-753.

57 Zgodnie z zasługującym na aprobatę stanowiskiem wyrażonym w uzasadnieniu wyroku SN z 19 listopada 2015 r. (IV CSK 792/14, Legalis nr 1364675): „pozbawienie wolności jest samoistną podstawą przyznania zadośćuczynienia”.

58 Sokołowski (2012): 122; por. Panowicz-Lipska (1975): 57 n.

59 Zob. wyroki SN: z 19 listopada 2015 r., IV CSK 792/14, Legalis nr 1364675; z 15 listopada 1979 r., II CR 376/79, Legalis nr 21740; podobnie wyrok SA w Katowicach z 7 czerwca 2018 r., II AKa 228/18, Legalis nr 1846341.

60 Zob. wyrok SA w Warszawie z 14 czerwca 2013 r., II Aka 165/13, Legalis nr 736314; Daszkiewicz (1989): 1-2. 
skazania ${ }^{61}$. Natomiast majątkowa ochrona szerzej rozumianej wolności jest obecnie możliwa na tle art. 448 k.c. w zw. z art. 23 k.c. Z reguły w tych sytuacjach dochodzi do naruszenia także innych dóbr (tj. nietykalności cielesnej, integralności, godności, zdrowia) ${ }^{62}$.

\section{ZNACZENIE WOLNOŚCI DLA STOSUNKÓW PRAWNOMEDYCZNYCH}

Gwarancje ochrony wolności człowieka w niezwykle silny sposób akcentowane sa w stosunkach prawnomedycznych ${ }^{63}$. Można nawet stwierdzić, że punktem w rozważaniach nad relacja pacjent-lekarz jest, obok autonomii, właśnie wolność. Zdaniem Pawła Łukowa dostrzec należy pewna ewolucję w myśleniu polegająca na „odchodzeniu od zakotwiczenia regulacji bioetycznych w godności i wysuwania na pierwszy plan wolności” ${ }^{64}$. Wyłania się na tym tle pytanie, jak należy rozumieć to wieloznaczne pojęcie w świetle prawa medycznego. Właściwe zdaje się, prima facie, utożsamianie wolności z pewna, co do zasady, nienaruszalną sfera, która przysługuje każdemu człowiekowi w takim samym zakresie i stopniu. Nie uzależnia się jej od płci, wieku, stanu zdrowia, zakresu zdolności do czynności prawnych. Natomiast autonomię człowieka (w ujęciu funkcjonalnym) postrzegać należy w kategoriach sposobu korzystania z wolności. Znajduje to swoje odzwierciedlenie w możliwości stanowienia i decydowania o sobie samym. W pewnym sensie nawiazuje to do koncepcji autonomii działania, która swój przejaw znajduje w konstytucyjnych, jak również ustawowych gwarancjach dotyczących wolności.

Szczególnie na tle stosunków prawnomedycznych można zauważyć, że wolność zmierza niejako do autonomii. Naruszenie autonomii jest bowiem równoznaczne z naruszeniem człowieczeństwa. Prowadzi to do przedmiotowego traktowania człowieka (np. w sytuacji gdy lekarz nie uwzględnia sprzeciwu świadomego, pełnoletniego i nieubezwłasnowolnionego pacjenta na udzielenie świadczenia zdrowotnego). Wolność związana jest $\mathrm{z}$ autonomią $\mathrm{w}$ dwojaki sposób. Po pierwsze, autonomia w swoim ujęciu funkcjonalnym urzeczywistnia przez działanie albo zaniechanie przysługującą człowiekowi wolności. Po drugie, autonomia postrzegana w kategoriach wartości jest „rdzeniem” wolności. Uznać należy bowiem, że każdy człowiek jest autonomiczny, chociaż nie wszyscy moga lub potrafią urzeczywistniać przysługująca im wolność. Pojęcie wolności osobistej pokrywa się więc z pozytywnym jej aspektem, chroniącym najszerzej ujmowaną możliwość samodecydowania (a więc autonomii w ujęciu funkcjonalnym) ${ }^{65}$.

${ }^{61}$ Zob. Księżak (2014): 278. Roszczenie z tego tytułu jest ograniczone wobec istnienia normy o charakterze lex specialis zawartej w przepisie art. 552 k.p.k. (w wypadku tymczasowego aresztowania lub zatrzymania); co do tego problemu zob. m.in. Bulsiewicz, Hofmański (1981): 37-49.

62 Zob. Mularski (2016): 1850.

63 Zob. np. Sobolewski (2017): 390-391; Michałowska (2014): 19-20.

${ }^{64}$ Łuków (2007): 20.

65 Karkowska (2016): 315. 
W relacji pacjent-lekarz wyróżnić należy wiele aspektów wolności. Przykładowo, swobodę wyboru lekarza ${ }^{66}$, prawo do decydowania o kluczowych kwestiach związanych z procesem udzielania świadczeń zdrowotnych, prawo wyboru pielęgniarki i położnej w zakresie podstawowej opieki zdrowotnej ${ }^{67}$, świadczeniodawcy udzielającego ambulatoryjnych świadczeń specjalistycznych spośród tych świadczeniodawców, którzy zawarli umowy o udzielanie świadczeń opieki zdrowotnej (art. 29 u.ś.o.z. ${ }^{68}$ ). To samo dotyczy wyboru szpitala (art. 30 u.ś.o.z.) oraz lekarza dentysty (art. 31 u.ś.o.z.).

Niezwykle istotne znaczenie ma również instytucja zgody (np. art. 17-18 u.p.p. ${ }^{69}$, art. 32 i 34 u.z.l. ${ }^{70}$, art. 3 pkt 4 u.o.z.p. ${ }^{71}$ ), która niejako „materializuje" wolność, natomiast pozbawienie możliwości jej wyrażania narusza autonomię pacjenta. Oczywiście autonomia nie powinna ograniczać się wyłącznie do decyzji o poddaniu się leczeniu i wyborze procedury. Istnieje wiele innych przejawów jej występowania na tle relacji pacjent-lekarz. Tytułem przykładu wskazać należy między innymi prawo pacjenta do: informacji, dokumentacji medycznej, leczenia bólu. Jednakowoż pacjent powinien być zawsze traktowany podmiotowo, tj. z poszanowaniem przysługujacej mu godności, wolności i autonomii (zwłaszcza w ujęciu funkcjonalnym). Ma to istotne znaczenie z punktu widzenia pozostałych, prawnie chronionych wartości, tj. integralności i nietykalności cielesnej. Wydaje się, że szczególnie w stosunkach medycznych dobra te wzajemnie przenikają się, a instytucja zgody gwarantuje ich respektowanie.

Zdarza się jednak, że autonomia, a co za tym idzie - również wolność, zostaje ograniczona ze względu na ochronę innych wartości (np. dobro ogółu). Dzieje się tak między innymi podczas udzielania świadczeń zdrowotnych bez zgody pacjenta czy konfrontowania autonomii pacjenta z autonomia lekarza w kontekście instytucji klauzuli sumienia ${ }^{72}$. Nie da się zaprzeczyć, że to właśnie w stosunkach prawnomedycznych wpływ sposobu pojmowania wolności, a także autonomii człowieka w zetknięciu z licznymi przykładami ograniczenia tej ostatniej w imię innych wartości jest najbardziej dostrzegalny.

Wypada w tym miejscu zauważyć, że nie jest możliwe ustalenie jednolitych oraz precyzyjnych granic dla samostanowienia jednostki. Przy rozstrzyganiu o zakresie oraz granicach autonomii (rozumianej w ujęciu funkcjonalnym) decydujaccą rolę odgrywać będzie sposób pojmowania naczelnej wartości w sys-

${ }^{66}$ Zob. Haberko (2016): 44; wyrok TK z 29 kwietnia 2003 r., SK 24/02, OTK-A 2003, nr 4, poz. 33 .

${ }^{67}$ Art. 9 ustawy z 27 października 2017 r. o podstawowej opiece zdrowotnej, t.jedn.: Dz. U. 2020, poz. 172 ze zm.

${ }^{68}$ Ustawa z 27 sierpnia 2004 r. o świadczeniach opieki zdrowotnej finansowanych ze środków publicznych, t.jedn.: Dz. U. 2021, poz. 1285 ze zm.

${ }^{69}$ Ustawa z 6 listopada 2008 r. o prawach pacjenta i Rzeczniku Praw Pacjenta, t.jedn.: Dz. U. 2020, poz. 849 ze zm.

${ }^{70}$ Ustawa z 5 grudnia 1996 r. o zawodach lekarza i lekarza dentysty, t.jedn.: Dz. U. 2021, poz. $790 \mathrm{ze} \mathrm{zm}$.

${ }^{71}$ Ustawa z 19 sierpnia 1994 r. o ochronie zdrowia psychicznego, t.jedn.: Dz. U. 2020, poz. 685 ze zm.

${ }^{72}$ Bosek (2014a): 14-25; (2014b): 87-104. 
temie prawnym, którą pozostaje godność osobowa. Jej immanentną cechą jest niezbywalność. Z tego między innymi powodu wykluczyć należy skuteczność takich działań, które mogłyby doprowadzić do jej utraty. Dlatego autonomia jako element tak pojętej godności wymaga zawsze konfrontacji z tym, co jest jej źródłem (czyli z godnościa). W tych zatem okolicznościach wydaje się, że jakakolwiek ingerencja w wolność oraz autonomię jest możliwa tylko wówczas, gdy spełnione zostaną przesłanki określone w art. 31 ust. 3 Konstytucji RP. Tym samym w przypadku pozostających ze sobą w kolizji wartości konieczne jest ich odpowiednie wyważenie dla osiagnięcia stanu zakładanego przez ustawodawcę ${ }^{73}$.

\section{PODSUMOWANIE}

W świetle powyższych, szczegółowych uwag można dojść do wniosku, że autonomia człowieka stanowi instrument urzeczywistniania wolności. Wolność jest więc pewną „sfera” przysługującą każdemu człowiekowi niezależnie od wieku, zakresu zdolności do czynności prawnych czy pochodzenia. Relacja między tymi wartościami polega więc na tym, że autonomia jako wartość współokreślająca godność realizuje przysługująca człowiekowi wolność. Przejawem znaczenia przypisywanego autonomii są w szczególności przepisy dotyczące wyrażania zgody na udzielenie świadczenia zdrowotnego.

Poszanowanie wolności człowieka wyraża się w zakazie dokonywania jakichkolwiek samowolnych ingerencji mających za przedmiot ciało innego człowieka $^{74}$. Każdy ma więc autonomię, w ramach której może podejmować decyzję i oznajmiać swoją wolę innym podmiotom, w tym także udzielającym świadczeń zdrowotnych. Z samego faktu istnienia tej wartości człowiek może zatem kształtować swoją sytuację prawna, w tym sytuację prawnomedyczna, w której występuje. Wszelkie ograniczenia muszą odpowiadać zasadzie proporcjonalności, w szczególności nie mogą naruszać istoty wolności czy autonomii. Chodzi o sytuacje, w których „nie tyle nie ma zgody pacjenta, ile zgody tej uzyskać nie można, a stan zdrowia wymaga od lekarza podjęcia natychmiastowego działania"75.

Autonomia jako sposób korzystania z wolności ulega jednak stopniowaniu. Wynika to z faktu, że zdolność do dokonywania czynności autonomicznych uzależniona jest zarówno od czynników wewnętrznych (stan zdrowia psychicznego), jak i zewnętrznych (np. działanie pod przymusem ${ }^{76}$. W tym ujęciu o autonomii można mówić wtedy, gdy osoba refleksyjna, podążając za pragnieniami - własnymi lub przez siebie akceptowanymi - podejmuje decyzję, na podstawie której następuje działanie. Wspomniane działanie musi być w pełni

\footnotetext{
${ }^{73}$ Zob. zwł. Wild (2016): 1181.

${ }^{74}$ Haberko, Wojcieszak (2019): 40.

75 Bernatek-Zaguła (2008): 82-83.

76 Haberko, Wojcieszak (2019): 41.
} 
zamierzone i w wystarczającym stopniu niezależne oraz zrozumiałe (dla podmiotu działającego). Tym samym o autonomii jako wartości rozprawiać należy w odniesieniu do osób, natomiast jako o sposobie korzystania z wolności - wobec działań. Powoduje to, że każdy człowiek jest autonomiczny, chociaż nie wszyscy mogą lub potrafią urzeczywistniać przysługującą im wolność.

Nie da się zaprzeczyć, że autonomia człowieka znajduje swoje oparcie w takich wartościach, jak: godność, wolność, prywatność, zdrowie, integralność i nietykalność cielesna ${ }^{77}$. W mniejszym lub większym stopniu jest komponentem (elementem) tychże wartości, w szczególności godności i wolności. Dlatego naruszenie wspominanych wartości jest jednoznaczne z naruszeniem autonomii. Wobec czego gwarancje wolności przewidziane przez system prawny zapewniają właściwą ochronę autonomii człowieka, jako że autonomia stanowi swoistą nić aksjologiczną, swój przejaw bowiem znajduje właśnie w wolności, którą urzeczywistnia.

Augustyniak, M. (2016). Pojęcie, istota oraz geneza wolności i praw człowieka, [w:] M. Chmaj (red.), Wolności i prawa człowieka w Konstytucji Rzeczypospolitej Polskiej. Warszawa: Wolters Kluwer: 13-31.

Balicki, R., Barciak, J., Preisner, A. (1998). Prawo konstytucyjne. Źródła, literatura, pytania kontrolne. Wrocław: Wydawnictwo Uniwersytetu Wrocławskiego.

Bernatek-Zaguła, I. (2008). Prawo pacjenta w Polsce do informacji medycznej. Toruń: Wydawnictwo Adam Marszałek.

Boratyńska, M., Konieczniak, P. (2019). Zasady prawa medycznego. Podstawy i przesłanki legalności czynności medycznych, [w:] M. Boratyńska, P. Konieczniak (red.), System prawa medycznego. Tom 2: Regulacja prawna czynności medycznych. Część 1. Warszawa: Wolters Kluwer: 25-209.

Bosek, L. (2012). Gwarancje godności ludzkiej i ich wpływ na polskie prawo cywilne. Warszawa: Wydawnictwo Sejmowe.

Bosek, L. (2014a). Prawo osobiste do odmowy działania sprzecznego z własnym sumieniem - na przykładzie lekarza. Forum Prawnicze 1: 14-25.

Bosek, L. (2014b). Problem zakresowej niekonstytucyjności art. 39 ustawy o zawodach lekarza i lekarza dentysty, [w:] P. Stanisz, J. Pawlikowski, M. Ordon (red.), Sprzeciw sumienia w praktyce medycznej - aspekty etyczne i prawne. Lublin: Wydawnictwo KUL: 87-104.

Bulsiewicz, A., Hofmański, P. (1981). Materialnoprawne warunki odpowiedzialności Skarbu Państwa za szkodę spowodowaną oczywiście niesłusznym tymczasowym aresztowaniem. Palestra 10/12: 37-49.

Chaciński, J. (2004). Prawa podmiotowe a ochrona dóbr osobistych. Lublin: Wydawnictwo KUL.

Daszkiewicz, W. (1989). Konstytucyjne gwarancje wolności osobistej. Rozważania de lege ferenda. Ruch Prawniczy, Ekonomiczny i Socjologiczny 51(2): 1-30.

Dudek, D. (1999). Konstytucyjna wolność człowieka a tymczasowe aresztowanie. Lublin: Lubelskie Wydawnictwa Prawnicze Marek Jakubek.

Dyka, I. (2001). Zasady przyznawania i ustalania wysokości zadośćuczynienia pieniężnego w razie naruszenia dobra osobistego. Kwartalnik Prawa Prywatnego 3: 596-637.

Fromm, E. (1970). Ucieczka od wolności. Warszawa: Wydawnictwo Czytelnik.

Garlicki, L. (2016). Komentarz do art. 30, [w:] L. Garlicki, M. Zubik (red.), Konstytucja Rzeczypospolitej Polskiej. Komentarz. Tom 2: Art. 30-86. Warszawa: Wydawnictwo Sejmowe: 27-54.

Granat, M. (2014). Prawo konstytucyjne w pytaniach i odpowiedziach. Warszawa: Wolters Kluwer.

77 Zob. art. 30, art. 41 ust. 1, art. 47, art. 51 ust. 1, art. 68 Konstytucji RP oraz pośrednio art. 38 Konstytucji RP. 
Grzybowski, S. (1957). Ochrona dóbr osobistych według przepisów ogólnych prawa cywilnego. Warszawa: Wydawnictwa Prawnicze.

Haberko, J. (2016). Zasady postępowania lekarza w stosunku do pacjenta. Uwagi de lege lata i de lege ferenda na tle przepisów Kodeksu etyki lekarskiej. Medyczna Wokanda 8: 43-56.

Haberko, J., Wojcieszak, A. (2019). O sytuacji pacjenta cierpiącego w kontekście prawa do leczenia bólu. Zeszyty Naukowe Centrum Badań im. Edyty Stein 21/22: 39-54.

Karkowska, D. (2016). Prawo pacjenta do wyrażenia zgody na udzielenie świadczeń zdrowotnych, [w:] D. Karkowska (red.), Ustawa o prawach pacjenta i Rzeczniku Praw Pacjenta. Komentarz. Warszawa: Wolters Kluwer: 312-440.

Kazimierczuk, M. (2014). Pojęcie, istota oraz źródło wolności i praw człowieka. Studia Prawnoustrojowe 26: 101-114.

Księżak, P. (2014). Komentarz do art. 23, [w:] M. Pyziak-Szafnicka, P. Księżak (red.), Kodeks cywilny. Część ogólna. Komentarz. Warszawa: Wolters Kluwer: 276-281.

Kurowski, K. (2014). Wolności i prawa człowieka i obywatela z perspektywy osób z niepełnosprawnościami. Warszawa: Biuro Rzecznika Praw Obywatelskich.

Lipiec, J. (1997). Wolność i podmiotowość człowieka. Kraków: Wydawnictwo Fall.

Łabno, A. (2002). Ograniczenie wolności i praw człowieka na podstawie art. 31 Konstytucji III RP, [w:] B. Banaszak, A. Preisner (red.), Prawa i wolności obywatelskie w Konstytucji RP. Warszawa: C.H. Beck: 695 .

Ławniczak, A. (2010). Zasada poszanowania wolności i jej ograniczenia, [w:] M. Jabłoński (red.), Wolności i prawa jednostki w Konstytucji RP. Tom 1: Idee i zasady przewodnie konstytucyjnej regulacji wolności praw jednostki w RP. Warszawa: C.H. Beck: 369.

Łuków, P. (2007). Etyczne podstawy świadomej zgody na postępowanie medyczne w Europejskiej Konwencji Bioetycznej. Prawo i Medycyna 4: 5-22.

Mazurek, F.J. (1980). Godność człowieka a prawa człowieka. Roczniki Nauk Społecznych 8: 19-48.

Michałowska, K. (2014). Charakter prawny i znaczenie zgody pacjenta na zabieg medyczny. Warszawa: Difin.

Mrozek, J.J. (2014). Godność osoby ludzkiej jako źródło praw człowieka i obywatela. Civitas et Lex 1: 41-47.

Mularski, K. (2016). Komentarz do art. 44, [w:] M. Gutowski (red.), Kodeks cywilny. Tom 1: Komentarz. Art. 1-44911. Warszawa: C.H. Beck: 1844-1851.

Panowicz-Lipska, J. (1975). Majątkowa ochrona dóbr osobistych. Warszawa: Wydawnictwo Prawnicze.

Przybyszewska-Szter, B. (2016). Wolności i prawa osobiste, [w:] M. Chmaj (red.), Wolności i prawa człowieka w Konstytucji Rzeczypospolitej Polskiej. Warszawa: Wolters Kluwer: 110-126.

Radwański, Z., Olejniczak, A. (2019). Prawo cywilne - część ogólna. Warszawa: C.H. Beck.

Sarnecki P. (1997). Idee przewodnie Konstytucji Rzeczypospolitej Polskiej z 2 kwietnia 1997 r. Przegląd Sejmowy 22(5): 9-32.

Sobolewski, P. (2017). Konstytucyjne uwarunkowania zgody na zabieg medyczny, [w:] M. Safjan, L. Bosek (red.), System prawa medycznego. Tom 1: Instytucje Prawa Medycznego. Warszawa: C.H. Beck: 388-394.

Sokołowski, T. (2012). Osoby fizyczne, [w:] A. Kidyba (red.), Kodeks cywilny. Komentarz. Tom 1: Część ogólna. Warszawa: Wolters Kluwer: 19-159.

Szpunar, A. (1979). Ochrona dóbr osobistych. Warszawa: PWN.

Wild, M. (2016). Komentarz do art. 47, [w:] M. Safjan, L. Bosek (red.), Konstytucja RP. Tom 1: Komentarz art. 1-86. Warszawa: C.H. Beck: 1161-1182.

Wiliński, P. (2011). Proces karny w świetle konstytucji. Warszawa: Wolters Kluwer.

Wiliński, P., Karlik, P. (2016). Komentarz do art. 41, [w:] M. Safjan, L. Bosek (red.), Konstytucja RP. Tom 1: Komentarz art. 1-86. Warszawa: C.H. Beck: 991-1006. 


\section{THE PROTECTION OF HUMAN AUTONOMY UNDER CERTAIN GUARANTEES OF FREEDOM}

\section{Sum mary}

This article synthetically presents the protection of human autonomy under certain guarantees of freedom. The considerations undertaken by the author focus primarily on determining what freedom is. Then, the issue of the protection of human autonomy is analysed from the perspective of the current legislative solutions guaranteeing the protection of freedom, in particular constitutional provisions, civil law provisions, and also some of the provisions regulating legal and medical relations. The purpose of this article is to present, on the one hand, the relationship between freedom and autonomy, and on the other, to determine whether the current regulations guarantee adequate protection of autonomy within the framework of guarantees concerning freedom.

Keywords: autonomy; human freedom; personal rights; human dignity; guarantees regarding the protection of freedom 
